\title{
A Preliminary Research on Consumer Acceptance in Nanofood towards Purchase Intention: A Pilot Research
}

\author{
Mohamad Aidil Hasim, Juhaini Jabar, Murzidah Ahmad Murad
}

\begin{abstract}
Nanofood is one of food technologies, which can enhance food safety, food taste, shelf life and packaging. The main goal of the study is to recognize the influencing factors impacting consumer acceptance in nanofood towards purchase intention. The study is based upon survey approach to collect the primary data from 65 respondents as preliminary pilot test. This research was fully conducted in quantitative study and implementation of research was conducted in Johor, Malaysia. $P 3$ Sweetener is an example product of the study. The model elicits four influencing factors which are knowledge, trust, perceived benefit and psychological. The findings based upon descriptive analysis and reliability test indicated that knowledge, trust, perceived benefit and psychological are significance in reliability test, /Cronbach's Alpha Coefficient (a) are greater than 0.70]. However, this is the preliminary stage of this research. The study has provided a data based on pilot study. Therefore, it should be considered for further research and addressing the upcoming studies.
\end{abstract}

Index Terms: Consumer acceptance, nanofood, pilot test, reliability test.

\section{INTRODUCTION}

Nanotechnology is the comprehension and control of nanoparticles of 1 to 100 nanometres, capable of constructing nano-structures, developing a new system with unique physical and biological features that permit a new application [1]. Nanotechnology has been implemented in several areas such as semiconductor and materials, electronics, pharmaceutical and healthcare, chemical, automotive and defense, food industry and others [2]. Food technology is one of the emerging food industry sectors. In food sectors, nanotechnology has been discovering many aspects of food, including the development of new food formulation, improvement of food packaging materials, advanced food security devices and biosensors to ameliorate food quality indices such as shelf life, sensory characteristics, improve texture of food and build health benefits product [3], [4].

The term of food technology is referring to a branch of food science which deals with the actual produces to make foods [5]. Nanofood was produced through the process of food technology. The term of nanofood is a combination of nanotechnology and food itself. Nanofood is referring to the

Revised Manuscript Received on July 10, 2019.

Mohamad Aidil Hasim, Faculty of Technology Management and Technopreneurship, Universiti Teknikal Malaysia Melaka (UTeM), Melaka, Malaysia.

Juhaini Jabar, Faculty of Technology Management and Technopreneurship, Universiti Teknikal Malaysia Melaka (UTeM), Melaka, Malaysia.

Murzidah Ahmad Murad, Faculty of Technology Management and Technopreneurship, Universiti Teknikal Malaysia Melaka (UTeM), Melaka, Malaysia. food that has been grown, produced, processed or packaged using nanotechnology tools or techniques, or has nanomaterial added into it [6]. In this context, this researcher used the P3 Sweetener product as an example of this study. P3 Sweetener product has been on the market in Malaysia since July 2013. According to [7], the main purpose of this product is to be an alternative and primary sweetener replacing white sugar and synthetic sweeteners. P3 Sweetener is extracted from 100\% of Sugar Cane Extract (SCE) in liquid form. This product was investigated and produced in PH 5.5, which is suitable for use in humans. In order to meet the needs of all Malaysian cultures, particularly hypertension, heart problem, kidney, diabetes, and obesity, P3 Sweetener is designed for these problems. This product helps consumers to prevent and reduce diabetes-related oxidative stress while regulating blood and sugar levels to a normal state. The cause of the diseases are unhealthy food, unbalanced diet and excessive daily sugar consumption, which led to the above-mentioned disease.

However, the novel food application remains uncertain in the practice of Malaysia. The importance of nanofood for their health should be understood. Therefore, its importance to enhance consumer understanding of the existence of nanofood and its application in food. Health exposure needs to be emphasized that consumers are aware that eating unhealthy foods and excessive sugars will be invaluable. Hence, switch to healthy eating and proper sugar intake such as P3 Sweetener and start changing the usual routine from white sugar to P3 Sweetener. As the saying, prevent it better than cure it.

\section{LITERATURE REVIEW}

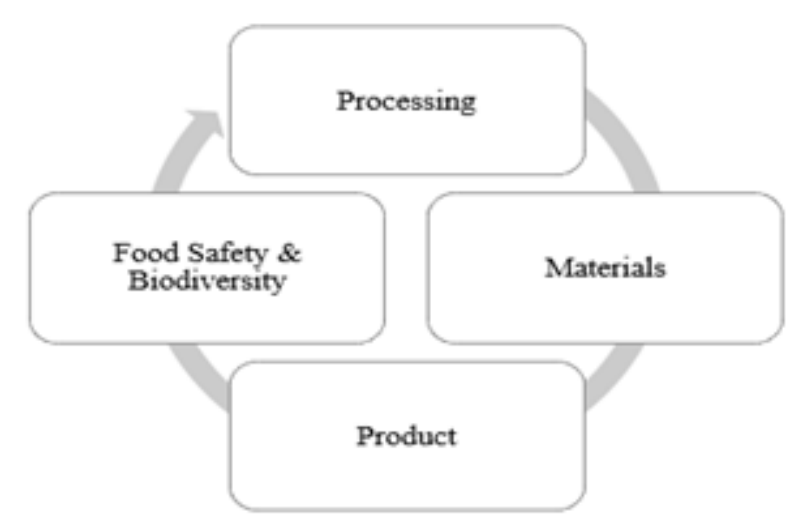

Fig. 1: Possible application in nanofood

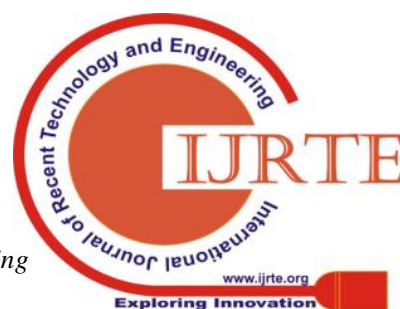




\section{A PRELIMINARY RESEARCH ON CONSUMER ACCEPTANCE IN NANOFOOD TOWARDS PURCHASE INTENTION: A PILOT RESEARCH}

According to [8], Fig. 1 shown the possible application in nanofood; i) food processing, (e.g.: heat/mass transfer, molecular synthesis, nanoscale reaction engineering) ii) design of materials, (e.g.: nanoparticles, nanocomposite, nanoemulsions, nanostructured material), iii) food product, (e.g.: packaging, delivery, formulation) and iv) food safety and biodiversity, (e.g.: nanosenor, nanotracer). It shown that nanofood can improve food safety and processing, improve food quality, improve taste and nutrition, delivery procedures, broaden pathogen detection, enhance food functionality, protect the environment and cost - efficiency of storage and distribution [9]. However, the result from previous research shown that consumer understanding and knowledge are still limited and some of them are not realized the existence of nanofood [10].

Therefore, it is pivotal for exposing consumers to the benefits of nanotechnology in foods widely. To ensure the successful of nanotechnology idea, the government has to play a crucial role, a successful campaign to promote consumer awareness of the impact of nanotechnology on future economies, societies and the environment must be promoted to disseminate the right information to the consumer. This is to ensure consumers are realized the existing of nanofood and practicing a healthy lifestyle.

\section{Proposed Research Model}

The idea of this proposed model was employed from the extension of Technology Acceptance Model (TAM) [11]. This researcher believed that the extension of TAM could determine consumer behavior towards their intentions. Therefore, the extension of TAM is the most appropriate theories utilized in this study since the extension of TAM focused on determinants of perceived usefulness and behavioral intention [12], [13]. In this study, consumer acceptance is the dependent variable, purchase intention is ultimate dependent variable, while cultural difference is moderator variable. There are 4 independent variables as shown below. Detailed justification for the inclusion of each independent variable in the model is specified below.

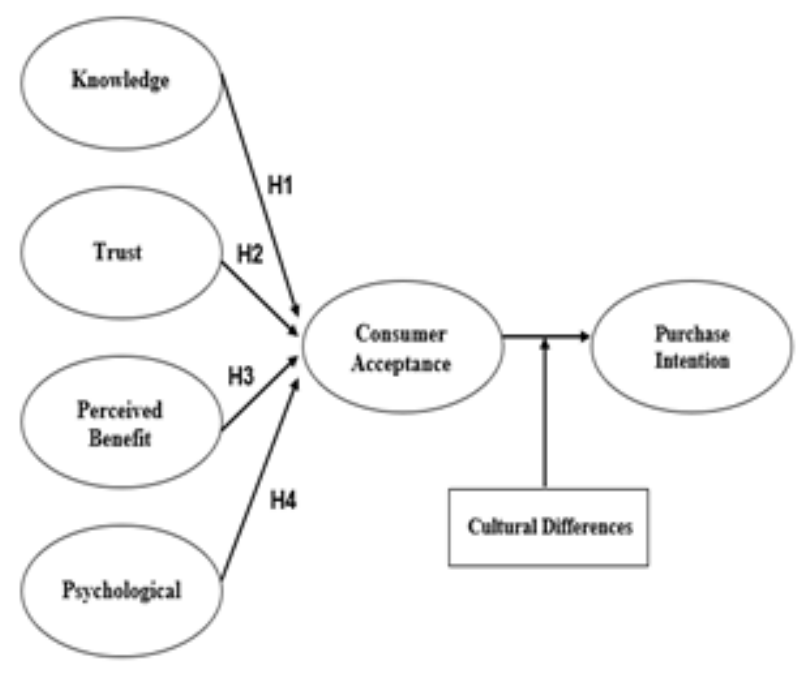

Fig. 2: Proposed research model

\section{Knowledge}

A person with a greater knowledge of nanotechnology could this better be able to identify the advantages and disadvantages of nanofood products. Nanotechnology knowledge is defined by this research as the level to be understood by the person [14]. If consumers are aware the existence of nanotechnology, they will learn more about the associated benefits and perhaps more prepared to try the related products. This is stated in the following hypothesis in the context of nanofoods:

H1. Knowledge is positively associated with consumer acceptance.

\section{Trust}

Trust is belief on something, belief the product or service can fulfill it is tasks as the buyers understood [15]. According to [16] showed that trust is a solid structure to determine the acceptance of food technologies and science. If people have trust in a product, the product will meet its desire for some level of effectiveness and thus the product is reliable. The next hypothesis is proposed as follows:

H2. Trust is positively associated with consumer acceptance.

\section{Perceived Benefit}

According to [17] showed that buyers are assessing perceived benefits based on product's function or performance. Therefore, this researcher assumed that if nanofood provide clear advantages to consumers, consumers would feel that consuming those products meets their related requirements and could also find nanofood more reliable and trustworthy. The following hypotheses are as follows:

H3. Perceived benefit is positively associated with consumer acceptance.

\section{Psychological}

Psychological have four factors driving actions in the quest for satisfaction: which is motivation, perception, learning, attitudes and beliefs [18]. In this context, motivation can influence consumer towards purchase behavior. It is very well explained by Maslow hierarchy theory. The following hypotheses are as follows:

H4. Psychological positively associated with consumer acceptance.

\section{METHODOLOGY}

\section{Design of Instrument}

An instrument was developed from the literature review to cover the fundamental research goals. The survey was divided into 4 parts. Part A captured the data about the demographic profile covering individual characteristics such as gender, age, ethnicity, education, know about nanotechnology, received any information about nanotechnology in food and through which platform the information was received. 
Part B covers the information about factors that influencing consumer acceptance. Table 1 included items measuring influencing factors on five-point Likert scale. All the information in Table 1 were adapted from previous literature review [19]-[23]. Research confirms that Likert data (and similar scales) are considerably less accurate when the number of scale points is below 5 or above 7 [24].

Part $\mathrm{C}$ of the instrument-included items that measure consumer acceptance, shown in Table 2. All items were adapted from [25], [26]. Part D covers the information about individual purchase intention towards nanofood. All items in Table 3 were adapted from [27]. By taking those instruments validated as reference points, this research developed a questionnaire as per below. Thus, all items were reworded to capture information about consumer willingness to purchase nanotechnology in food.

Table 1: Influencing factors

\begin{tabular}{|c|c|c|c|}
\hline No. & Items & Mean & SD \\
\hline \multicolumn{4}{|c|}{ Knowledge (KN) } \\
\hline KN1 & $\begin{array}{l}\text { I know nanometer is a billionth of } \\
\text { a meter }\end{array}$ & 4.18 & 0.864 \\
\hline KN2 & $\begin{array}{l}\text { I know nanotechnology in food } \\
\text { involves materials that are not } \\
\text { visible to the naked eye }\end{array}$ & 4.35 & 0.799 \\
\hline KN3 & $\begin{array}{l}\text { I know nanofood can extend } \\
\text { human life span }\end{array}$ & 4.06 & 0.768 \\
\hline KN4 & $\begin{array}{l}\text { I know how to use nanofood and } \\
\text { its function }\end{array}$ & 4.00 & 0.771 \\
\hline KN5 & $\begin{array}{l}\text { I realized the existence of } \\
\text { nanofood in the market (e.g.: P3 } \\
\text { sweetener liquid drop and P3 } \\
\text { sweetener nanosugar) }\end{array}$ & 4.26 & 0.815 \\
\hline \multicolumn{4}{|c|}{ Trust (TR) } \\
\hline TR1 & $\begin{array}{l}\text { I trust the scientific analysis of } \\
\text { nanofood }\end{array}$ & 4.15 & 0.833 \\
\hline TR2 & $\begin{array}{l}\text { I trust nanofood because of the } \\
\text { brand (e.g.: P3 Sweetener) }\end{array}$ & 4.23 & 0.745 \\
\hline TR3 & $\begin{array}{l}\text { I trust the product because of } \\
\text { awareness toward its quality }\end{array}$ & 4.29 & 0.723 \\
\hline TR4 & $\begin{array}{l}\text { I have an experience of using } \\
\text { nanofood before }\end{array}$ & 4.12 & 0.820 \\
\hline TR5 & $\begin{array}{l}\text { I trust the product because of its } \\
\text { safety to consume }\end{array}$ & 4.17 & 0.802 \\
\hline \multicolumn{4}{|c|}{ Perceived Benefit (PB) } \\
\hline PB1 & $\begin{array}{l}\text { I believe that nanofoods have } \\
\text { extra nutrition }\end{array}$ & 4.15 & 0.712 \\
\hline PB2 & $\begin{array}{l}\text { I believe nanofood can enhance } \\
\text { the taste of the food }\end{array}$ & 4.05 & 0.694 \\
\hline PB3 & $\begin{array}{l}\text { I believe nanofood can extend the } \\
\text { shelf life of the food }\end{array}$ & 4.00 & 0.771 \\
\hline PB4 & $\begin{array}{l}\text { I believe that nanofoods have the } \\
\text { advantage of helping the body } \\
\text { absorb nutrition more easily }\end{array}$ & 4.00 & 0.685 \\
\hline PB5 & $\begin{array}{l}\text { I believe that nanofood is } \\
\text { beneficial }\end{array}$ & 4.18 & 0.748 \\
\hline \multicolumn{4}{|c|}{ Psychological (PS) } \\
\hline PS1 & $\begin{array}{l}\text { I believed brand name is very } \\
\text { important consideration } \\
\text { purchase decision. }\end{array}$ & 4.34 & 0.713 \\
\hline PS2 & $\begin{array}{l}\text { I believed "Word of Mouth" can } \\
\text { motivate my decision to purchase }\end{array}$ & 4.15 & 0.712 \\
\hline
\end{tabular}

\begin{tabular}{|c|l|c|c|}
\hline & intention & & \\
\hline PS3 & $\begin{array}{l}\text { I believed advertisement and } \\
\text { promotional can influence my } \\
\text { decision to purchase. }\end{array}$ & 4.00 & 0.612 \\
\hline PS4 & $\begin{array}{l}\text { I believed price can influence my } \\
\text { decision to purchase }\end{array}$ & 4.02 & 0.673 \\
\hline PS5 & $\begin{array}{l}\text { I realized nanofood content can } \\
\text { help improve my health }\end{array}$ & 4.17 & 0.741 \\
\hline
\end{tabular}

$* \mathrm{SD}=$ Standard Deviation

Table 2: Consumer acceptance

\begin{tabular}{|c|l|c|c|}
\hline No. & \multicolumn{1}{|c|}{ Items } & Mean & SD \\
\hline CA1 & I would eat nanofood & 4.17 & 0.698 \\
\hline CA2 & $\begin{array}{l}\text { I would serve nanofood to my } \\
\text { family and friends }\end{array}$ & 4.05 & 0.672 \\
\hline CA3 & $\begin{array}{l}\text { I would purchase foods labelled as } \\
\text { containing nanofood in the grocery } \\
\text { store. }\end{array}$ & 3.98 & 0.718 \\
\hline CA4 & $\begin{array}{l}\text { Nanotechnology in food should be } \\
\text { encouraged }\end{array}$ & 4.20 & 0.814 \\
\hline CA5 & $\begin{array}{l}\text { I will use nanofood because it is } \\
\text { easy to use. }\end{array}$ & 4.11 & 0.831 \\
\hline CA6 & $\begin{array}{l}\text { I will buy the nanofood because it } \\
\text { is safety to consume }\end{array}$ & 4.17 & 0.720 \\
\hline
\end{tabular}

$* \mathrm{SD}=$ Standard Deviation

Table 3: Purchase intention

\begin{tabular}{l|l|l|l|}
\hline No. & \multicolumn{1}{|c|}{ Items } & Mean & SD \\
\hline Purchase Intention (PI) & 4.29 & 0.744 \\
\hline PI1 & It is safe to eat & 4.25 & 0.708 \\
\hline PI2 & It provides a variety of nutrients & 4.18 & 0.705 \\
\hline PI3 & It reduces health problem & 4.23 & 0.702 \\
\hline PI4 & It is better for my health & 3.91 & 0.605 \\
\hline PI5 & I follow my family and friend & 4.02 & 0.673 \\
\hline PI6 & Society says it as a good choice & &
\end{tabular}
$* \mathrm{SD}=$ Standard Deviation

\section{Instrument Reliability and Validity}

A pilot test was conducted by giving out 65 samples of questionnaires to consumer through online survey administrated via Google.Docs. 55 samples of questionnaires were given to real consumers and another 10 samples were given to academician (experts) to check for grammatical errors and content validity. The questionnaire was answered based on their observations and understanding. The questionnaire was reworded to enhance the clarity. Table 4 shown the result of Cronbach's Alpha Coefficient $(\alpha)$ as a measurement tools in determining the reliability test.

Table 4: Reliability test

\begin{tabular}{|c|c|c|c|c|}
\hline No. & Constructs & Mean & $\mathrm{SD}$ & $\begin{array}{c}\text { Cronbach's } \\
(\alpha)\end{array}$ \\
\hline 1 & Knowledge & 4.1723 & 0.7131 & 0.971 \\
\hline 2 & Trust & 4.1938 & 0.7158 & 0.966 \\
\hline 3 & $\begin{array}{l}\text { Perceived } \\
\text { Benefit }\end{array}$ & 4.0769 & 0.6429 & 0.963 \\
\hline 4 & Psychological & 4.1354 & 0.6053 & 64 \\
\hline
\end{tabular}


A PRELIMINARY RESEARCH ON CONSUMER ACCEPTANCE IN NANOFOOD TOWARDS PURCHASE INTENTION: A PILOT RESEARCH

\begin{tabular}{|c|c|c|c|c|}
\hline 5 & $\begin{array}{c}\text { Consumer } \\
\text { Acceptance }\end{array}$ & 4.1128 & 0.6575 & 0.961 \\
\hline 6 & $\begin{array}{c}\text { Purchase } \\
\text { Intention }\end{array}$ & 4.1462 & 0.5874 & 0.966 \\
\hline
\end{tabular}

$* \mathrm{SD}=$ Standard Deviation

$*(\alpha)=$ Cronbach Alpha

\section{Data Collection}

The study is based upon survey approach to collect the primary data from 65 respondents that consuming nanofood (P3 Sweetener product) as preliminary pilot test. This research was fully conducted in quantitative method and data collection was distributed in Johor, Malaysia.

\section{RESULTS AND DISCUSSION}

About 65 received questionnaires were analyzed for descriptive analysis and reliability test using SPSS version 23, which predict consumer acceptance in nanofood towards purchase intention. Table 5 describes the characteristics of respondents.

Table 5: Characteristics of respondents

\begin{tabular}{|c|c|c|}
\hline Characteristics & Items & Frequency \\
\hline \multirow[t]{2}{*}{ Gender: } & Male & 42 \\
\hline & Female & 23 \\
\hline \multirow[t]{5}{*}{ Age: } & $21-25$ years old & 2 \\
\hline & $26-30$ years old & 5 \\
\hline & $31-35$ years old & 11 \\
\hline & $36-40$ years old & 6 \\
\hline & 41 and above & 41 \\
\hline \multirow[t]{4}{*}{ Ethnicity: } & Malay & 49 \\
\hline & Chinese & 11 \\
\hline & Indian & 3 \\
\hline & Other & 2 \\
\hline \multirow[t]{10}{*}{ Education: } & SRP & 5 \\
\hline & PT3 / PMR & 0 \\
\hline & SPM & 13 \\
\hline & A Level / Foundation & 0 \\
\hline & STPM & 4 \\
\hline & Diploma & 18 \\
\hline & Bachelor Degree & 7 \\
\hline & Master Degree & 6 \\
\hline & $\mathrm{PhD}$ & 10 \\
\hline & Other & 2 \\
\hline \multirow[t]{3}{*}{$\begin{array}{c}\text { Know about } \\
\text { nanotechnology: }\end{array}$} & $\begin{array}{c}\text { Technology at the } \\
\text { nanoscale }\end{array}$ & 17 \\
\hline & $\begin{array}{l}\text { Nanomaterials which } \\
\text { have one or more } \\
\text { dimensions in the range } \\
1-100 \mathrm{~nm} .\end{array}$ & 35 \\
\hline & $\begin{array}{l}\text { Creation of functional } \\
\text { materials, devices and } \\
\text { systems through control } \\
\text { of matter on the } \\
\text { nanometer length scale. }\end{array}$ & 13 \\
\hline \multirow[t]{2}{*}{$\begin{array}{l}\text { Receive any } \\
\text { information: }\end{array}$} & Yes & 65 \\
\hline & No & 0 \\
\hline \multirow[t]{3}{*}{ Platform received: } & Book & 18 \\
\hline & Magazine & 5 \\
\hline & Blog & 7 \\
\hline
\end{tabular}

\begin{tabular}{|c|c|}
\hline Website & 23 \\
\hline Other & 12 \\
\hline
\end{tabular}

According to [28], the perfectly adequate reliability index where the best figure should exceed 0.70 . The result of reliability test in Table 4 shown that all constructs $(\alpha)$ are greater than 0.70. Thus, all variables constructed are accepted. As a pilot study, the survey provides a basic understanding based on constructed questionnaires. Therefore, the descriptive analysis results and the reliability test were shown in this paper.

\section{CONCLUSION}

This preliminary study was based upon a survey of 65 respondents that consumed nanofood. The study identified the significance reliability test for all variables constructed. The result shown that all variables constructed are significance (greater than 0.70) and accepted. However, the study has provided a data based on pilot study of this researcher. Therefore, for further research and the forthcoming studies should be addressed.

\section{ACKNOWLEDGMENT}

The researchers would like to thank Faculty of Technology Management and Technopreneurship, Universiti Teknikal Malaysia Melaka (UTeM) for supporting the implementation of this research and this researcher also like to express thanks to Associate Professor Dr Juhaini Jabar and Dr Murzidah Ahmad Murad for assistance in conducting this research.

\section{REFERENCES}

1. H. Hamdan, "NanoMalaysia Programme (2011-2020): Engine of growth for innovative Malaysia," Journal of Experimental Nanoscience, 9(1), 2010, pp. 2-8.

2. Vasco Teixeira, Opportunities and challenges in nanotechnology-based on food packaging industry. 2015, Available:

https://www.slideshare.net/teixeiravasco/opportunitiesand-challenges-in-nanotechnologybased-food-packagingindustry?qid=2bb20fc5-75e2-4cab-8322-

dac09c6201f5\&v=\&b=\&from_search $=3$.

3. S. Khezri, E. M. Kia, M. M. Seyedsaleh, S. Abedinzadeh, and M. Dastras, "Application of nanotechnology in food industry and related health concern challenges," International Journal of Advanced Biotechnology and Research, 7(Special Issue-Number2-April), 2016, pp. 1370-1382.

4. Q. Huang, Nanotechnology in the Food, Beverage and Nutraceutical Industries. Cambridge: Woodhead Publishing Limited, 2012.

5. B. Bigliardi, and F. Galati, "Innovation trends in the food industry: The case of functional foods," Trends in Food Science and Technology, 31(2), 2013, pp. 118-129.

6. B. S. Sekhon, "Food nanotechnology-An overview," Nanotechnology, Science and Applications, 3, 2010, pp. 1-15.

7. P Three Sweetener Global Sdn. Bhd, Home. Available: https://p3sweetener.com.my/. 
8. J. Weiss, P. Takhistov, and D. J. McClements, "Functional materials in food nanotechnology," Journal of Food Science, 71(9), 2006, pp. R107-R116.

9. L. Rashidi, and K. Khosravi-Darani, "The applications of nanotechnology in food industry," Critical Reviews in Food Science and Nutrition, 51(8), 2011, pp. 723-730.

10. R. I. van Giesen, A. R. Fischer, and H. C. van Trijp, "Changes in the influence of affect and cognition over time on consumer attitude formation toward nanotechnology: A longitudinal survey study," Public Understanding of Science, 27(2), 2018, pp. 168-184.

11. V. Venkatesh, and F. D. Davis, "A theoretical extension of the technology acceptance model: Four longitudinal field studies," Management Science, 46(2), 2000, pp. 186-204.

12. F. Abu, A. R. Yunus, L. A. Majid, J. Jabar, A. Aris, H. Sakidin, and A. Ahmad, "Technology Acceptance Model (TAM): Empowering smart customer to participate in electricity supply system," Journal of Technology Management and Technopreneurship, 2(1), 2014, pp. 8594.

13. J. Jabar, M. H. A. Karim, S. W. M. Yusof, M. A. Murad, and F. A. Khalid, "Adoption attitude towards the usage of pusher box technology in the rubber industry," Advances in Social Sciences Research Journal, 4(4), 2017, pp. 1-9.

14. M. F. Chen, Y .P. Lin, and T. J. Cheng, "Public attitudes toward nanotechnology applications in Taiwan," Technovation, 33(2-3), 2013, pp. 88-96.

15. R. Seppanen, K. Blomqvist, and S. Sundqvist, "Measuring inter-organizational trust - A critical review of the empirical research in 1990-2003," Industrial Marketing Management, 36(2), 2007, pp. 249-265.

16. L. Bredahl, "Determinants of consumer attitudes and purchase intentions with regard to genetically modified foods - Results of a cross-national survey," Journal of Consumer Policy, 24(1), 2001, pp. 23-61.

17. A. L. Vandelannoitte, "Managing BYOD: How do organizations incorporate user-driven IT innovations," Information Technology and People, 28(1), 2015, pp. 233.

18. B. Vainikka, Psychological factors influencing consumer behaviour. Bachelor thesis, Centria University of Applied Sciences, 2015

19. H. H. Chang, C. Y. Huang, C. S. Fu, and M. T. Hsu, "The effects of innovative, consumer and social characteristics on willingness to try nano-foods: Product uncertainty as a moderator," Information Technology and People, 30(3), 2017, pp. 653-690.

20. B. Schnettler, G. Crisostomo, M. Mora, G. Lobos, H. Miranda, and Grunert, "Acceptance of nanotechnology applications and satisfaction with food-related life in southern Chile," Food Science and Technology, 34(1), 2014, pp. 157-163.

21. T. P. Brankov, T. Sibalija, K. Lovre, D. Cvijanovic, and J. Subic, "The impact of biotechnology knowledge on the acceptance of genetically modified food in Serbia," Romanian Biotechnological Letters, 18(3), 2013, pp. 8295-8306.

22. R. Ravichandran, "Nanotechnology applications in food and food processing: Innovative green approaches, opportunities and uncertainties for global market," International Journal of Green Nanotechnology: Physics and Chemistry, 1(2), 2010, pp. P72-P96.

23. P. A. Zawislak, L. F. Marques, P. Esteves, and F. Rublescki, "Technological trajectories and multidimensional impacts: further remarks on the nanotechnology industry," Journal of Business Chemistry, 7(1), 2010, pp. 47-64.

24. R. Johns, Survey Question Bank: Methods Fact Sheet 1 March

2010 ,

Available: https://www.sheffield.ac.uk/polopoly_fs/1.597637!/file/li kertfactsheet.pdf.

25. T. Singh, S. Shukla, P. Kumar, V. Wahla, V. K. Bajpai, and I. A. Rather, "Application of nanotechnology in food science: Perception and overview," Frontiers in Microbiology, 8, 2017, pp. 1-7.

26. M. S. Kim, Nanotechnology and food: The perception and level of acceptance of nanotechnology use in foods. PhD thesis, New Brunswick: State University of New Jersey, 2014.

27. P. Pomsanam, K. Napompech, and S. Suwanmaneepong, "Factors driving Thai consumers' intention to purchase organic foods," Asian Journal of Scientific Research, 7(4), 2014, pp. 434-446.

28. K. S. Taber, "The use of Cronbach's alpha when developing and reporting research instruments in science education," Research in Science Education, 48(6), 2018, pp. 1273-1296. 